\title{
PARADIGMA DAN EPISTEMOLOGI DAKWAH
}

\author{
Abdullah \\ Guru Besar Fakultas Dakwah dan Komunikasi \\ Universitas Islam Negeri Sumatera Utara
}

\begin{abstract}
ABSTRAK
Paradigma dan epistemologi memegang peranan penting dalam perkembangan suatu disiplin ilmu. Paradigma dimaknai sebagai pandangan yang mendasar tentang apa yang menjadi pokok persoalan dalam ilmu pengetahuan. Berdasarkan paradigma tertentu, ilmuwan merumuskan obyek atau sasaran ilmu dan permasalahannya, serta menentukan metode yang dipakai untuk mencari jawaban dari suatu masalah. Sementara epistemologi merupakan cabang atau sub dari filsafat yang membicarakan hakikat, batasan, prosedur keilmuan yang ditempuh untuk menghasil pengetahuan ilmiah. Paradigma dakwah telah bergeser dari tablig kepada rekontruksi masyarakat Islam berdasarkan pesan-pesan Alquran, melalui dakwah bil-lisan, bil-kitabah dan bil hal. Sementara epistemologi dakwah mulai bergeser dari pemikiran normatif - deduktif kepada pemikiran rasional - empiris.
\end{abstract}

Kata Kunci : Paradigma, epistemologi dan pengembangan Ilmu Dakwah

\begin{abstract}
Paradigm and epistemology play an important role in the development of a scientific discipline. The paradigm is interpreted as a fundamental view of what is the main problem in science. Based on a certain paradigm, scientists formulate the object or target of science and their problems, and determine the methods used to find answers to a problem. While epistemology is a branch or sub of philosophy that discusses the nature, boundaries, scientific procedures taken to produce scientific knowledge. The paradigm of da'wah has shifted from tabliq to the reconstruction of Islamic societies based on the messages of the Qur'an, through the preaching bil-lisan, bil-kitabah dan bil hal. While the epistemology of da'wah began to shift from normative thought - deductive to rational thought empirical.
\end{abstract}

Keywords: Paradigm, epistemology and the development of Da'wah

\section{PENDAHULUAN}

Perkembangan dakwah sebagai suatu disiplin ilmu menurut Azyumardi Azra relatif lambat ${ }^{1}$ bila dibandingkan dengan perkembangan ilmu keislaman

${ }^{1}$ Azyumardi Azra, "Kata Pengantar" dalam A. Ilyas Ismail, Paradigma Dakwah Sayyid Quthub: Rekonstruksi Pemikiran Dakwah Harakah, (Jakarta: Penamadani, 2008), h.xxix. 
lainnya. ${ }^{2}$ Hal ini kuat dugaan berkaitan dengan latar belakang pendirian Fakultas Dakwah pada tahun 1968 dan the founding father pada waktu itu diduga masih menganut paradigma tablig. ${ }^{3}$

Hasil penelusuran ditemukan bahwa pemikiran perlunya kehadiran Fakultas Dakwah adalah untuk melahirkan para dai dan daiyah yang memiliki latar belakang akademis yang mampu mengantisipasi problem umat Islam dalam pembangunan nasional. ${ }^{4}$ Pada awalnya dakwah masih dipandang identik dengan tablig, hal itu terlihat dengan jelas dari jurusan pada awal kelahirannya, yaitu Jurusan Tablig dan Penyiaran Islam. ${ }^{5}$ Demikian juga halnya dengan literatur dakwah selama tahun 1960-1977 bahwa pembahasannya masih didominasi dalam perspektif tablig. ${ }^{6}$

\subsection{Paradigma Dakwah Kontemporer}

Pada awal tahun 80-an hingga saat ini, dakwah sebagai disiplin ilmu mendapat perhatian yang serius dari para akademisi dan pakar dakwah, dengan melakukan berbagai pertemuan ilmiah yang membahas dakwah dari berbagai aspeknya termasuk aspek Filsafat Ilmu $^{7}$. Dari berbagai pertemuan ilmiah pada

${ }^{2}$ Ilmu keislaman dibagi kepada delapan bidang, yaitu Tafsir/Ulumul Qur'an, Hadis/Ulumul Hadis, Dakwah Islam, Fiqh/Pranata Sosial, Sejarah Kebudayaan Islam, Pemikiran dalam Islam, Bahasa/Sastra Arab dan Pendidikan Islam. Lihat, Amin Abdullah, Islamic Studies di Perguruan Tinggi: Pendekatan Integratif-Interkoneksi, (Yogyakarta: Pustaka Pelajar, 2006), h.74.

${ }^{3}$ Fakultas Dakwah tertua di Indonesia berada di IAIN Ar-Raniry Banda Aceh, berdiri tahun 1968 dan sebelumnya hanya merupakan Jurusan Dakwah di Fakultas Ushuluddin. Lihat, Moh. Ali Aziz, Ilmu Dakwah, (Jakarta: Prenada Media, 2015), h. 90-91.

${ }^{4}$ Amrullah Ahmad, "Sistem Pendidikan Fakultas Dakwah," dalam Media Dakwah, No.241, Juli 1994, h.33.

${ }^{5}$ Aziz, Ilmu,... h. 91.

${ }^{6}$ Lihat antara lain, Barmawi Umari, Asas-Asas Ilmu Dakwah, (1961), Mahmud Yunus, Pedoman Dakwah Islamiyah, (1965), Toha Jahja Omar, Ilmu Dakwah (1967), K. H. Isa Anshari, Mujahid Da'wah, (1967), Chadijah Nasution, Ilmu Dakwah (1970), A. Mukti Ali, Faktor-Faktor Penyiaran Islam (19971), Hamzah Ya'qub, Publisistik Islam: Teknik Dakwah dan Leadership (1973), A. Hasjmy, Dustur Dakwah Menurut Al-Qur'an, (1974), KI M. A. Machfoeld, Filsafat Da'wah: Ilmu Da'wah dan Penerapannya, (1975), Rosyad Shaleh, Manajemen Dakwah, (1977).

${ }^{7}$ Seminar Nasional dengan tema "Dakwah Islam dan Perubahan Sosial" yang diselenggarakan oleh Pusat Pelatihan, Penelitian dan Pengembangan Masyarakat Yogyakarta, tahun 1982, sangat menggelitik dan menjadi cambuk bagi pakar dakwah dalam merumuskan keilmuan dakwah selanjutnya. Hasil seminar tersebut kemudian dijadikan buku dan diterbitkan tahun 1983. 
tingkat nasional telah berhasil dirumuskan tentang paradigma ${ }^{8}$ dakwah yang lebih jelas. Pertama, dakwah tidak identik dengan tablig, ceramah dan pidato keagamaan, melainkan mencakup dakwah tiga serangkai atau dakwah integratif, yaitu bil lisan, bil kitabah dan bil hal . Kedua, dakwah dimaknai sebagi upaya rekontruksi masyarakat Islam $^{10}$ sesuai dengan cita-cita sosial Islam dengan adagium Islam Rahmatan lil 'alamin (ISRA). Ketiga, dakwah telah memilki konsep dan landasan teori, baik melalui pendekatan normatif-deduktif maupun empiris-induktif, yang dapat dijadikan pijakan dalam berdakwah untuk pembangunan masyarakat lahir dan batin. Keempat, dakwah sejajar dengan disiplin ilmu keislaman lainnya, karena telah memiliki aspek ontologi, epistemologi dan aksiologi yang jelas. Dakwah dipahami melalui penjelasan dari Alquran dan Hadis, hal ini dinamakan dengan pendekatan normatif-deduktif. Sementara memahami perilaku manusia sebagai penerima dakwah disebut pendekatan empiris atau induktif.

Berdasarkan paradigma di atas, dakwah merupakan upaya rekonstruksi masyarakat dengan misi penyebaran dan pembumian Islam sepanjang sejarah dan sepanjang zaman. Kegiatan tesebut dilakukan melalui lisan (bil-lis $\pm n$ ), tulisan (bil$k i t \pm b a h)$ dan perbuatan $(b i l-h \pm l)$. Ini artinya dakwah menjadi misi abadi untuk sosialisasi nilai-nilai Islam dan upaya rekonstruksi masyarakat sesuai dengan adagium Islam rahmatan $\operatorname{lil}^{6} \pm \operatorname{lam}^{3} n$ (ISRA) yaitu rahmat bagi alam semesta atau rahmat untuk sejagat ${ }^{11}$. Model masyarakat yang ingin diwujudkan adalah umat terbaik atau istilah Alquran khaira ummah ${ }^{12}$ di mana aktifitas amr makruf nahi munkar berjalan dan terjalin secara berkelanjutan. Nabi Muhammad Saw. telah

${ }^{8}$ Istilah ini pertama kali diperkenalkan oleh Thomas Kuhn melalui bukunya The Structure of Scientific Revolution. Paradigma memiliki cakupan asumsi, konsep, atau proposisi logis, yang mengarahkan cara berpikir dan penelitian. Secara etimologis, istilah paradigma berasal dari bahasa Yunani yaitu dari kata "para" yang artinya di sebelah atau di samping, dan kata "diegma" berarti teladan, ideal, model, atau pun arketipe. Sedangkan secara terminologis, istilah paradigma diartikan sebagai sebuah pandangan atau cara pandang yang digunakan untuk menilai dunia dan alam sekitarnya, yang merupakan gambaran atau pun perspektif untuk menjabarkan berbagai macam permasalahan dunia nyata yang sangat kompleks.

${ }^{9}$ Lihat, M. Arifin, Psikologi Dakwah: Suatu Pengantar, (Jakarta: Bumi Aksara, 1991), h.6. h.27.

${ }^{10}$ M. Amien Rais, Cakrawala Islam: Antara Cita dan Fakta, (Bandung: Mizan, 1987),

${ }^{11}$ Lihat Alquran surah al-Anbiya' [21] ayat 107.

${ }^{12}$ Lihar Alquran surah Ali Imran [3] ayat 110. 
berhasil membangun umat terbaik pada zamannya sebagaimana pengakuan dari Alquran. ${ }^{13}$

Pandangan di atas menempatkan dakwah sebagai tugas besar, tugas penting ${ }^{14}$ dan mulia. Tugas tersebut pada mulanya diemban oleh para nabi, sejak Nabi Adam as hingga Nabi Muhammad Saw. Para nabi telah melaksanakan tugas mulia itu dengan sukses, namun tetap menghadapi berbagai tantangan dan rintangan. Hal yang sama juga dialami oleh mujahid dan rijalud dakwah sejak masa sahabat hingga dewasa ini.

Di era globalisasi saat ini selain peluang, dakwah juga menghadapi berbagai tantangan yang sangat berat, terutama dampak dari kemajuan ilmu pengetahuan dan teknologi. Oleh sebab itu, kajian terhadap pengembangan konsep dakwah dan evaluasi terhadap gerakan (harakah) dakwah dewasa ini harus terus dilakukan secara intensif. ${ }^{15}$ Pemikir, akademisi dan pengurus organisasi dakwah dituntut untuk merevisi dan terus mengembangkan konsep dakwah dan gerakan dakwah yang lebih sesuai dengan tuntutan zaman, sehingga aktivitas dakwah mampu menawarkan solusi terhadap problematika kehidupan masyarakat modern dan pascamodern.

\subsection{Dari Ontologi Menuju Epistemologi Dakwah}

\section{Objek Material dan Objek Formal Ilmu Dakwah}

Sebelum lebih jauh, membahas tentang epistemologi dakwah, maka perlu disingguh tentang objek Ilmu Dakwah. Ilmu Dakwah sebagai suatu disiplin ilmu sebagaimana ilmu lainnya memiliki dua objek kajian yaitu objek material dan objek formal. Para pakar dakwah di tanah air, berbeda pendapat tentang objek material Ilmu Dakwah. Pendapat pertama bahwa objek material Ilmu Dakwah adalah Alquran dan Hadis, sedangkan pendapat kedua objek formalnya adalah manusia. Pendukung pendapat pertama antara lain Amrullah Ahmad dan Ahmad Subandi. Sementara pendukung pendapat kedua antara lain Moh. Ali aziz. Kedua

\footnotetext{
${ }^{13}$ M. Quraish Shihab, Tafsir Al-Mishbah: Pesan, Kesan dan Keserasian Al-Qur'an (Jakarta: Lentera Hati, 2006), h. 184.

${ }^{14}$ Lihat Alquran surah Lukman [31] ayat 17.

${ }^{15}$ A. Ilyas Ismail, membagi empat aliran dakwah, yaitu dakwah paradigma tablig, dakwah paradigma pengembangan masyarakat, dakwah paradigma harakah, dan dakwah paradigma kultural. Lihat, A. Ilyas Ismail dan Prio Hotman, Filsafat Dakwah: Rekayasa Membangun Agama dan Peradaban islam, (Jakarta: Prenada Media, 2011), h.213-214.
} 
pendapat tersebut perlu didiskusikan secara serius, karena hal ini persoalan mendasar dalam merekonstuksi bangunan Ilmu Dakwah.

Bagi yang bependapat objek material Ilmu Dakwah adalah Alquran dan Hadis, hal ini sejalan dengan pandangan Sayyid Quthub dan A. Mukti Ali bahwa Islam agama dakwah. Islam sebagai agama samawi bersumber dari Alquran sebagai sumber utama dan Hadis sebagai sumber kedua. Tidak hanya Ilmu Dakwah, keislaman lainnya pun mepunyai objek material yang sama, seperti Ulum Alquran, Asbabun Nuzul, Ilmu Tafsir. Bahkan hampir semua ilmu tentang keislaman, objek materialnya adalah Alquran. Dari sinilah, kemudian kajiannya dikembangkan sesuai dengan fokus kajian masing-masing. Fokus kajian itu disebut dengan objek formal.

Objek formal Ilmu Dakwah merupakan suatu objek yang dapat membedakannya dari objek kajian dari disiplin ilmu lainnya. Jadi objek formal Ilmu Dakwah yaitu proses pengolahan, penyampaian dan penginternalisasian pesan-pesan keagamaan pada seluruh perilaku manusia dalam interaksi religius masyarakat di mana manusia hidup. Dengan perkataan lain, objek formal Ilmu Dakwah itu adalah proses pengolahan, penyampaian, dan penerimaan ajaran Islam untuk merubah perilaku individu, kelompok dan masyarakat sesuai dengan ajaran Islam. $^{16}$

Menurut Amrullah Ahmad, objek formal Ilmu Dakwah adalah mengkaji salah satu sisi objek material, yaitu kegiatan mengajak umat manusia agar masuk ke jalan Allah (sistem Islam) dalam semua segi kehidupan. Bentuk mengajak terdiri dari mengajak dengan lisan (bil lis $\pm n$ ), dakwah dengan perbuatan, keteladanan, demonstrasi, dakwah pembangunan dan aksi sosial (bil $h \pm l$ ), dan mengorganisir serta mengelola kegiatan dakwah secara efisien dan efektif, juga secara sistematis, koordinasi, singkronisasi dan integrasi program dengan pemanfaatan sumberdaya yang tersedia. ${ }^{17}$

Kegaitan mengajak dengan lisan dikenal dengan istilah tabligh Islam, kegiatan melalui aksi sosial disebut dakwah bil $h \pm l$ dan pengorganisasian kegiatan dakwah serta mengelolanya disebut dengan manajemnen dakwah Islam.

\footnotetext{
${ }^{16}$ Subandi, Ilmu Dakwah: Pengantar Kearah Metodologi (Bandung, Yayasan Syahida), h. $51-52$

${ }^{17}$ Amrullah Ahmad, "Dakwah Islam Sebagai Ilmu” (makalah tidak diterbitkan), h. 37.
} 
Sedangkan pemberian bimbingan, khususnya bagi individu atau bagi sekolompok kecil masyarakat Muslim yang memiliki problem kehidupan disebut dengan bimbingan dan penyuluhan Islam. Keempat kegiatan tersebut termasuk dalam kajian Ilmu Dakwah.

\section{Program Studi dan Objek Formal Ilmu Dakwah}

Secara lebih tegas, Ilmu Dakwah mempunyai aspek kajian khusus yang dikelompok berdasarkan program studi pada Fakultas Dakwah dan Komunikasi. Saat ini (existing) terdapat empat program studi, yaitu Program Studi Pengembangan Masyarakat Islam (PMI), Program Studi Manajemen Dakwah (MD), Program Studi Komunikasi dan Penyiaran Islam (KPI) dan Program Studi Bimbingan dan Penyuluhan Islam (BPI) atau Bimbingan dan Konseling Islam (BKI). Kemudian sehubungan dengan konversi IAIN ke UIN, sebahagian Fakultas Dakwah telah membuka program studi Ilmu Komunikasi dan program studi lainnya untuk menyahuti perkembangan zaman.

a. Program Studi Pengembangan Masyarakat Islam (PMI)

Kajian masalah yang berkaitan dengan prodi ini fokus pembahasan adalah teori-teori pembangunan, ekonomi dan kewiraswastaan. Semuanya dididekati dengan ajaran Islam. Penguasaan tentang sumberdaya alam (SDA) dan sumberdaya manusia (SDM) serta kemampuan mempertemukan keduanya menjadi penting dalam konteks pemberdayaan masyarakat. Lulusan dari prodi ini diharapkan mampu meningkatkan kesejahteraan masyarakat melalui dakwah bil $h \pm l$. Sebagai lapangan pengabdian alumni prodi ini, mereka diharapkan dapat bekerja antara lain pada (1). Kementerian Dalam Negeri (2). Kementerian Sosial (3). Lembaga Swadaya Masyarakat (LSM) dan Non Government Organization (NGO) dan (4).Pengusaha muslim.

b. Program Studi Manajemen Dakwah (MD)

Kajian pada prodi ini hal-hal yang berkaitan dengan manajemen Islami. Selain ilmu manajemen, fokus pembahasan prodi Manajemen Dakwah adalah lembaga-lembaga atau institusi keagamaan. Lulusan dari jurusan ini, diharapkan mampu mengelola lembaga dakwah dan institusi keagamaan secara profesional. Lulusan prodi ini diharapkan mengelola lembaga, 
organisasi dan sistem kekerabatan dalam masyarakat dapat dikelola dengan baik, sesuai dengan fungsi manajemen. Bidang pengabdian dari alumni prodi ini antara lain (1). Pengurus organisasi keagamaan (2). pengurus partai politik dan politikus (3). Pengurus Badan Amil Zakat (BAZ) dan Lembaga Amil Zakat (LAZ) (d). Karyawan pada Bank Syari'ah (4). Pengurus koperasi.

c. Program Studi Komunikasi dan Penyiaran Islam (KPI).

Mata kuliah yang dipelajari pada program studi ini dititikberatkan pada kumunikasi, jurnalistik, psikologi, teknik pidato (retorika) dan media komunikasi (media massa). Secara umum, dua hal yang menjadi titik fokus KPI, yaitu dakwah bil-lis $\pm n$ dan bil-kit \pm bah. Dakwah bil-lis $\pm n$, membicarakan persoalan tabligh, dakwah melalui mimbar atau dakwah jama'ah dan dakwah melalui tulisan. Lulusan (output) yang dihasilkan dari prodi ini diharapkan memiliki dua kemampuan (keahlian), yaitu kemampuan retoris dan jurnalis. Bila dua kemampuan tersebut dapat dimiliki, maka lapangan pengabdian yang dapat dimasuki adalah: (1). wartawan (2). penulis, yaitu penulis buku, artikel (artikel keagamaan dan opini) (3). pegawai pada perusahaan percetakan (4). pimpinan perusahaan percetakan (5). dai atau muballigh (khatib) (6). presenter dan MC (master of ceremony) (7). penyiar televisi dan radio.

d. Program Studi Bimbingan dan Penyuluhan Islam (BPI) Kajian yang berkaitan dengan teknik terapi terhadap masyarakat yang menghadapi masalah, baik individu, keluarga dan kelompok kecil dalam masyarakat melalui bimbingan dan penyuluhan Islam. Eksistensi kajian dan praktek dari program studi ini menjadi sangat penting saat ini. Sebab masyarakat modern menghadapi banyak persoalan dalam hidupnya, dan sangat menonjol adalah depresi dan stress. Teori-teori mengenai bimbingan dan penyuluhan (guide and counselling), menjadi fokus, di samping ilmu psikologi. Kompetensi yang harus dimiliki oleh output jurusan ini sekurangkurangnya ahli dalam psikoterapi Islam. Berdasarkan kepada kompetensi tersebut, maka lapangan pengabdian bagi mereka adalah sebagai rohaniawan dan konselor pada: (1). rumah sakit (2). lembaga pemasyarakatan (3). panti asuhan (4). psikolog pada perusahaan, dan (5). mediator di pengadilan. 
Setiap bidang kajian pada program studi di atas memiliki aspek yang membedakan dengan program studi lainnya. Sementara hubungan dan interaksi antar program studi (unsur) dalam masing-masing bidang yang berbeda itu, menjadi satu kesatuan dalam kajian Ilmu Dakwah. Keempat pembidangan di atas merupakan gambaran umum tentang program studi yang ada di Fakultas Dakwah dan Komunikasi saat ini.

Dalam rangka merekonstruksi dan pembangunan masyarakat Islam dalam perspektif dakwah, keempat bidang ilmu berdasarkan program studi seperti digambarkan di atas dapat hadir secara bersama-sama atau berurutan. Jika hadir secara berurutan, maka kepakaran berdasarkan keilmuan pengembangan masyarakat Islam (PMI) harus hadir terlebih dahulu.

Program studi ini bertugas membuat pemetaan (mapping), tentang kondisi okjektif di tengah-tengah masyarakat. Hasil pemetaan, kemudian dilanjutkan oleh manajemen dakwah (MD) untuk mengelola berdasarkan fungsi manajemen. Selanjutkan hadir sarjana komunikasi dan penyiaran Islam (KPI) untuk merubah mindset masyarakat. Adapun problem-problem individu, keluarga dan kelompok kecil diatasi secara khusus dengan pendekatan bimbingan dan penyuluhan Islam (BPI).

Jika cara berfikir seperti itu dapat disepakati, maka upaya rekontruksi masyarakat secara holistik dapat tercapai. Namun sayang sekali selama ini kegiatan dakwah berjalan secara parsial kalau bukan sporadis. Di sinilah perlunya duduk bersama antara pemikir dengan para praktisi dakwah.

Tuntutan Alquran agar orang beriman, beragama secara kaffah, yaitu tuntutan menjadikan semua bidang kehidupan untuk pengabdian dan penyerahan diri secara total kepada Allah Swt. Seperti disebutkan oleh M. Amien Rais bahwa kegiatan politik, juga kegiatan ekonomi, usaha-usaha sosial, gerakan-gerakan budaya, kegiatan-kegiatan ilmu dan teknologi, kreasi seni, kodifikasi hukum dan lain sebagainya, bagi seorang muslim adalah menjadi alat dakwah. ${ }^{18}$ Pada setiap bidang itu, harus dikembangkan dan ditegakkan serta dikelola sesuai dengan prinsip-prinsip Islam.

\footnotetext{
${ }^{18}$ M. Amien Rais, Cakrawala Islam (Bandung : Mizan, 1991), hlm. 27.
} 
Seiring dengan perkembangan terminologi, maka ruang lingkup dakwah pun menjadi berkembang. Dakwah secara umum telah dikelompokkan ke dalam tiga bentuk, yaitu dakwah secara lisan, melalui tulisan dan dakwah melalui aksi sosial, dakwah pembangunan dan dengan keteladanan atau lazim disebut dakwah bil hal.

\section{PEMBAHASAN}

\subsection{Epistemologi Dakwah}

Pada awalnya istilah epistemologi digunakan dalam filsafat yang berhubungan dengan metode dalam mendapatkan pengetahuan yang sah dan juga berhubungan dengan asal, sifat dan batas-batas ilmu pengetahuan. Menurut Jujun S. Suriasumantri, epistemologi disebut juga dengan teori pengetahuan, yang membahas secara mendalam segenap proses yang terlibat dalam usaha untuk memperoleh pengetahuan. ${ }^{19}$ Sementara ilmu merupakan pengetahuan yang didapatkan melalui proses tertentu yang dinamakan metode keilmuan. Dengan perkataan lain, ilmu adalah pengetahuan yang diperoleh dengan menerapkan metode keilmuan. Selanjutnya dapat ditegaskan bahwa ilmu (science) merupakan bahagian dari pengetahuan (knowledge), yaitu pengetahuan ilmiah yang lazim disebut dengan ilmu. ${ }^{20}$

Selanjutnya dapat dipahami bahwa ilmu pengetahuan merupakan hasil pemahaman manusia terhadap hukum-hukum objektif yang menguasai alam, ide dan meterial. Pemahaman tersebut lalu disistematisir, diklasifikasi serta diverifikasi dengan metode ilmiah, akhirnya lahirlah ilmu pengetahuan baik yang berupa studi empirik maupun studi eksperimen. Sebahagian diantaranya digolongkan ilmu alam (natural science) dan sebahagian yang lain digolongkan sebagai ilmu sosial (social science). Menurut Undang-Undang Republik Indonesia Nomor 12 tahun 2012, tentang Pendidikan Tinggi bahwa rumpun ilmu dibagi kepada enam, yaitu rumpun ilmu agama, rumpun ilmu humaniora, rumpun ilmu sosial, rumpun ilmu alam, rumpun ilmu formal dan rumpun ilmu terapan.

Sementara Ilmu Dakwah merupakan hasil sintesis antara sumber normatif Alquran dan Hadis- dan pengalaman empiris tentang perilaku manusia yang

\footnotetext{
${ }^{19}$ Jujun S. Suriasumantri, Ilmu Dalam Perspektif (Jakarta: Yayasan Obor Indonesia, 1983), h. 9.

${ }^{20}$ Ibid.
} 
berkaitan dengan penerimaan dan pengamalan agama. Dari kedua hal itu, kemudian dirumuskan menjadi Ilmu Dakwah.

Dakwah sebagai suatu disiplin ilmu, sesungguhnya sudah menemukan jati diri, walaupun dalam membahas Ilmu Dakwah diperlukan suatu sintesis pendekatan dari beberapa disiplin ilmu lain. Untuk itu ada beberapa hal yang perlu diperhatikan. Pertama, sintesis ini diharapkan mampu untuk lebih dapat memahami fenomena keagamaan yang menjadi bagian dari kehidupan kaum muslimin sehari-hari. Kedua, pemahaman yang lebih komprehensif dan tepat terhadap ajaran agama sehingga dapat membangkitkan suatu reaktualisasi ajaran Islam. Pemahaman seperti ini lebih memungkinkan menjadi penentu sikap, tingkah laku sekaligus terinternalisasi dalam kehidupan pribadi, keluarga dan dalam masyarakat muslim. Pada tahap yang lebih lanjut agama akan menjadi pembahagia dan sekaligus sebagai solusi dalam menghadapi tantangan dan problematika kehidupan masyarakat modern. Ketiga, melalui pendekatan fungsi dan tugas agama di satu pihak dan Ilmu Dakwah pada pihak lain, mahasiswa, praktisi dakwah atau siapa saja yang mendalaminya dapat memanfaatkan ilmu dakwah untuk memperbaiki posisi dan peranannya yang lebih menentukan di tengah-tengah perubahan zaman.

Dengan demikian memahami ilmu dakwah secara lebih elementer diharapkan dapat menjadikan pijakan dalam menentapkan dinamika masa depan. Oleh karena itu harus dikembangkan teori besar (grand theory) dengan disiplin ilmu dakwah yang mendasarkan diri dan mengacu kepada ajaran Islam dengan pengembangkan teori-teori yang sudah ada. Kemudian diharapkan dapat dikembangkan teori jangka menengah (midle range theory) untuk dirumuskan hipotesis lebih lanjut. Dengan demikian lambat laun akan dapat dibangun suatu kerangka keilmuan dakwah yang lebih kokoh.

Di kalangan cendekiawan Muslim Indonesia, sudah lama muncul pertanyaan mengenai cakupan kajian ilmu dakwah. Pertanyaan ini muncul karena adanya desakan bahwa dewasa ini sangat dibutuhkan konsep-konsep yang jelas mengenai metode dan sistem dakwah yang mampu memberikan arahan dalam menyongsong dan mengarungi segala perubahan yang sedang terjadi dalam masyarakat Indonesia dan masyarakat dunia. 
Pada tataran nasional, banyak persoalan kebangsaan sejak era reformasi hingga dewasa ini yang belum terselesaikan, antaranya masalah disintegrasi bangsa, keterbelakangan, kesenjangan, kemiskinan, lapangan kerja, ketidaktaatan pada hukum dan aturan, narkoba, perjudian hingga masalah korupsi. Dari waktu ke waktu selama dua dasawarsa terakhir, hal itu sangat mengganggu kehidupan berbangsa. Dalam lingkaran masalah tersebut perlu dipertanyakan peran dakwah untuk memberi solusi. Oleh karena itu, kondisi tersebut perlu mendapat perhatian serius para pemikir dan praktisi dakwah. Kondisi nasional dan global yang sedang mendera menuntut kontribusi riil dari pemikir dan praktisi dakwah untuk merespon secara tepat melalui konsep dan gerakan dakwah.

Konsep dan bentuk aplikasi dakwah yang dilaksanakan selama ini, mulai digugat, karena dipandang kurang mampu untuk berjalan secara seiring dengan kemajuan ilmu pengetahuan dan dinamika masyarakat serta problematika kebangsaan dan antarbangsa. Secara lebih khusus tidak mampu mengatasi masalah akbar, yaitu terjadinya proses dehumanisasi. ${ }^{21}$ Lalu muncul pertanyaan yang sangat menggelitik, tidak adakah konsep dakwah yang mampu mengatasi malapetaka itu?

Namun menurut M. Dawam Rahardjo, Ilmu Dakwah telah mengalami perkembangan yang menggembirakan. Menurutnya prinsip-prinsip Ilmu Dakwah telah lama diterapkan dalam berbagai bidang kegiatan, tidak hanya di perguruan tinggi, melainkan di berbagai tempat, seperti pada kursus-kursus dalam pengkaderan dai oleh lembaga dakwah. Tapi secara lebih mendasar tinjauan tentang eksistensi Ilmu Dakwah memang perlu pemikiran dan usaha merestrukturisasai Ilmu Dakwah, sehingga lebih jelas baik aspek ontologi, epistemologi dan aspek aksiologinya. Dengan demikian Ilmu Dakwah diharapkan lebih menduduki peringkat penentu dalam pengembangan keilmuan yang mampu mengadakan kontrol, dan prediksi terhadap masa depan. ${ }^{22}$

Ilmu Dakwah dalam penerapannya memiliki mitra kerja dengan berbagai ilmu sosial lainnya. Karena itu Ilmu Dakwah dalam perkembangannya seiring

\footnotetext{
${ }^{21}$ Nurcholis Madjid. Islam Kemodernan dan Keindonesiaan (Bandung: Mizan, 1987), h. 130 .

${ }^{22}$ M. Dawam Rahardjo, Intelektual Inteligensia dan Perilaku Politik Bangsa (Bandung : Mizan, 1999), h.158.
} 
dengan perkembangan kehidupan masyarakat. Antara Ilmu Dakwah dan perkembangan masyarakat saling berkaitan dan saling memengaruhi. Pada satu sisi dakwah berupaya memberikan solusi terhadap problem kehidupan masyarakat melalui konsep dakwah, dan pada sisi lain perkembangan dan masalah yang timbul dalam masyarakat menuntut pemikiran baru untuk pengembangan konsep dakwah.

Kerangka keilmuan dakwah (body of knowledge) mempunyai cakupan yang amat luas, yaitu seluas unsur-unsur dakwah itu sendiri. Unsur dakwah juga adalah unsur yang dinamis yaitu selalu mengalami perubahan kearah kesempurnaan, unsur tersebut seperti dai (daiyah), mad'u (audience), metode, media dan tujuan. Kemudian secara lebih spesifik peranan kajian keilmuan dan metodologinya melekat dalam berbagai dimensi dakwah - dakwah bil lis $\pm n$, bil kit \pm bah dan dakwah bil $h \pm l$ - mulai dari tujuannya, prosesnya, faktor-faktor yang mempengaruhi dakwah, pengukuran dan hasilnya. Setiap dimensi itu juga mempunyai landasan yang kuat serta memiliki nilai filosofisnya.

Bila dilihat dari struktur keilmuan, Ilmu Dakwah tidak bisa dipaksakan untuk mengikuti jejak ilmu-ilmu lainnya. Sebagai suatu disiplin ilmu, Ilmu Dakwah berkembang melalui tahap-tahap tertentu, yang menunjukkan pada tingkat kedewasaan ilmu ini.

Dalam perkembangannya Ilmu Dakwah tampak mengalami suatu pergeseran dari pemikiran yang didominasi oleh pendekatan spekulatif normatif ke arah pemikiran yang rasional dan kritis. Hal ini menunjukkan Ilmu Dakwah bukan lagi kegiatan yang steril dari beberapa aspek yang empiris dan ilmiah, melainkan telah memadukan antara pemikiran kefilsafatan dan emperis. Ilmu dakwah bukan lagi terletak pada tujuan, melainkan pada keseluruhan aspek dakwah atau unsur dakwah yang berwawasan masa depan.

Selain itu, Ilmu Dakwah baik prinsip maupun penerapannya bukanlah hal yang statis, melainkan sangat dinamis yang selalu mengikuti perkembangan dan perubahan masyarakat. Sifat seperti ini akan memungkinkan Ilmu Dakwah pada masa-masa akan datang mengalami perkembangan lebih maju dan semakin matang. Hal itu tergantung kepada akdemisi, khususnya dosen pemangku mata 
kuliah Ilmu Dakwah yang diberikan amanah yang berkaitan dengan Tri Dharma Perguruan Tinggi, khususnya dalam bidang penelitian.

Tugas Tri Dharma Perguruan Tinggi satu sama lain - pendidikan pengajaran, penelitian dan pengabdian masyarakat - sifatnya adalah siklus bukan linier. Artinya pendidikan dan pengajaran harus berbasis penelitian dan hasil penelitian harus dipraktikkan dalam pengabdian masyarakat. Dengan demikian Ilmu Dakwah akan berkembang seiring dengan dinamika dan perkembangan masyarakat.

Ilmu dakwah yang bersifat dinamis itu akan memberikan identitas dan eksistensi Fakultas Dakwah dan Komunikasi, di samping faktor-faktor lainnya seperti sejarahnya, penampilannya dalam melakoni peranannya, aturan atau kebijakan dan hal-hal lainnya. Dengan pendekatan yang sistematis dan komprehensif Ilmu Dakwah akan mampu merumuskan dan menjadikan Islam sebagai suatu sistem kehidupan manusia yang sempurna (kaffah). Dengan kata lain, melalui Ilmu Dakwah dapat dikembangkan konsep sekaligus operasionalnya, bahwa Islam tidak lagi dipahami sebagai sebuah agama dalam makna yang sempit, tapi Islam harus menjadi pandangan hidup yang dapat diaplikasi dalam berbagai kehidupan umat manusia yang majemuk dan heterogen.

\subsection{Metode Pengembangan Ilmu Dakwah}

Salah satu syarat suatu disiplin ilmu adalah memiliki metode dalam penemuan dan pengembangannya. Syarat ini sama pentingnya dengan syarat lainnya seperti harus memiliki objek, baik objek material maupun objek formalnya. Di samping syarat lain bahwa suatu disiplin ilmu harus bersifat universal dan memiliki nilai pragmatis, yaitu bermanfaat atau bernilai guna bagi kehidupan manusia.

Dalam setiap bidang keilmuan mempunyai metode tersendiri sebagai ciri khusus dari disiplin ilmu yang bersangkutan. Jadi metode atau metodologi bukanlah dominasi dan hak milik disiplin ilmu tertentu. Tapi setiap bidang keilmuan mempunyai metode tersendiri yang sering berbeda dengan metode keilmuan lainnya. 
Dalam kajian dakwah dikenal dua metode, yaitu metode keilmuan dakwah dan metode penyampaian dakwah. Dalam konteks ini yang akan dipaparkan adalah metode keilmuan dakwah. Menurut Amrullah Achmad, ada lima metodologi yang mungkin dapat digunakan dalam merumuskan dan mengembangkan konsep-konsep dakwah. ${ }^{23}$

\section{Analisis Sistem Dakwah}

Sistem sering diberi batasan sebagai suatu entitas (system as an entity) yaitu satu kesatuan. Suatu sistem merupakan kumpulan unsur yang mungkin berupa benda atau perihal yang membentuk suatu unit yang satu sama lain saling berkaitan dan saling mempengaruhi dalam mencapai tujuan. ${ }^{24}$ Dalam bahasa Arab disebut dengan nizham, yaitu keteraturan atau sesuatu yang tersusun secara baik dan susunannya itu mempunyai uslub atau urutan atau cara tertentu. Sesungguhnya dakwah adalah suatu sistem, karena dalam kegiatan dakwah melibatkan beberapa unsur, baik sebagai unsur utama maupun sebagai unsur pelengkap. Unsur-unsur itu terdiri dari dai (subjek), mad'u (mitra dakwah), materi, metode, media dan tujuan.

Metode ini melihat dakwah secara integral dan holistik. Selama ini ketika peran dakwah tidak signifikan di tengah-tengah masyarakat, maka kritikan atau kesalahan sering dialamatkan kepada dai atau organisasi dakwah. Cara pandang seperti ini adalah keliru dan dapat berpengaruh terhadap perumusan konsep dakwah yang parsial. Sementara dalam aplikasinya dakwah melibatkan semua unsur termasuk mitra dakwah dan media.

Dakwah sebagai suatu sistem, yang bermakna bahwa unsur-unsur dakwah satu sama lain saling berkaitan dan saling mempengaruhi dalam pencapaian tujuan. Jadi dalam perumusan dan pengembangan metode keilmuan dakwah dapat ditempuh dengan mengadakan analisis unsur-unsur dakwah yang disebutkan di atas. Untuk keperluan ini sangat dituntut pemahaman yang komprehensif dan mendalam terhadap tiap-tiap unsur dakwah. Dari analisis unsur tersebut diharapkan dapat dikembangkan metode keilmuan dakwah, hingga dirumuskan konstruksi keilmuan dakwah. Misalnya merumuskan materi dakwah untuk

\footnotetext{
${ }^{23}$ Ahmad, Dakwah Islam Sebagai, ... h.42.

${ }^{24}$ M.Syafa'at Habib, Buku Pedoman Da'wah (Jakarta: Widjaya, 1982), h.154.
} 
segmen tertentu, yaitu materi dakwah untuk pencandu narkoba, pekerja seks komersial dan berbagai segmen lainnya.

\section{Metode Historis}

Salah satu pemaknaan terhadap sejarah adalah rekontruksi masa lalu. Menurut Kontowijoyo sejarah mebicarakan masyarakat dari segi waktu. Empat hal yang dibicarakan berkaitan dengan waktu yaitu perkembangan, kesinambungan, pengulangan dan perubahan. ${ }^{25}$ Metode historis dalam konteks pengembangan Ilmu Dakwah adalah melakukan pengkajian terhadap sejarah dakwah. Kemudian merumuskan hal-hal yang substansi tentang perjalanan dakwah.

Perjalanan sejarah Islam telah mencapai bilangan lima belas abad. Selama kurun waktu tersebut, secara empiris gerakan dakwah sangat kaya dengan pengalaman dan hal inilah yang perlu ditelusuri satu persatu. Metode historis adalah mengkaji aplikasi dakwah pada masa lalu, yaitu dakwah masa Rasulullah saw, zaman sahabat (khulafa ar-rasyid-n), pada masa Bani Umayyah, Abbasiyah dan zaman berikutnya hingga saat ini. Aktivitas dakwah pada kurun waktu, tempat subyek dan objek dakwah yang berbeda-beda itu sungguh telah memberikan konstribusi yang amat berharga dalam merumuskan konsep-konsep dakwah yang lebih antisipatif untuk saat ini dan dalam menyonsong masa depan yang lebih kompetitif.

Dengan memahami sejarah dakwah Islam pada masa lalu secara filosofis dan akan mampu menangkap isyarat-isyarat penting dari gerakan (harakah) dakwah, baik mengenai kemajuan maupun kemundurannya dan mengkaitkan dengan tempat dan masyarakat yang dihadapi, tentu akan memberikan pengayaan informasi dalam merumuskan konsep-konsep baru. Harakah dakwah sepanjang sejarah seperti disebutkan di atas adalah dapat memberikan konstribusi pemikiran, yang perlu disintesakan menjadi suatu kristalisasi pemikiran dakwah dalam bentuk yang lebih dinamis untuk dijadikan rujukan dalam pengembangan dan pelaksanaan dakwah masa depan. Karena penggalan waktu masa lalu, masa kini dan masa depan, selalu saja dapat dihubungkan dan ditarik benang merahnya.

\footnotetext{
${ }^{25}$ Kontowijoyo, Pengantar Ilmu Sejarah (Yogyakarta: Bentang, 2005), h. 14.
} 


\section{Metode Reflektif}

Motode ini bertitik tolak dari pandangan "dunia tauhid" sebagai paradigma ke dalam prinsip epistemologi dakwah. Kegiatan refleksi ini sekaligus merupakan proses verifikasi atas prinsip-prinsip serta konsep-konsep dasar dakwah, yaitu apakah dakwah telah benar-benar merupakan upaya penampakan "wahyu Tuhan di permukaan bumi". Cara kerjanya adalah melalui analisis antara das sollen dengan das sein. Hasil kajian atas fakta dakwah yang dipadukan dengan wawasan teoritik digeneralisasi dalam rangka mengabstraksikan temuan-temuan dalam fakta empiris, kemudian merumuskan kerangka teoritik tentang dakwah sesuai dengan spesifikasi dan lingkup objek yang dikaji. Hasilnya boleh jadi memperkuat wawasan teori yang ada atau merevisi wawasan teori atau bahkan menggugurkan teori yan ada.

\section{Metode riset dakwah partisipatif}

Dakwah merupakan fenomena aktual yang berinteraksi dengan aneka ragam sistem kemasyarakatan, ilmu dan teknologi. Setiap masalah dakwah tidak bisa dikaji secara parsial atau terpisah dan dinetralisir kajiannya dengan aspek masalah lainnya. Hal ini karena masalah dakwah bersifat multi demensi dan selalu bersentuhan dengan aneka realitas. Untuk itu, kajian kedakwahan sangat diperlukan pendekatan empiris. Meskipun dalam sejarah epistemologi Islam pendekatan ini kurang diperaktekkan oleh pakar muslim dalam memahami kajian keilmuannya, mereka pada umummnya lebih menekankan pada pendekatan rasional.

Oleh karena itu dalam mengembangkan teori dakwah yang merupakan prasyarat keberhasilan dakwah, maka perlu menggunakan pendekatan empiris. Dengan pendekatan ini diharapkan akan ditemukan teori, sistem dan metode yang akurat yang memiliki kemampuan untuk dijadikan alat analisa lapangan (medan), memotret profil mad'u, menyusun program dakwah, menganalisis tahapan proses, pencapaian tujuan, memecahkan masalah yang dihadapi serta mampu mengantisipasi masalah yang komplek. 


\section{Riset Kecenderungan Gerakan Dakwah}

Dalam metode ini setelah melakukan generalisasi atas fakta atau peta dakwah masa lalu dan saat sekarang serta melakukan kritik terhadap teori-teori dakwah yang ada, maka peneliti dakwah menyusun analisis kecenderungan masalah, sistem, metode, pola pengorganisasian dan pengelolaan dakwah yang terjadi pada masa lalu, kini dan kemungkinan masa yang akan datang. Dengan riset ini kegiatan dakwah akan dapat tampil memandu perjalanan umat dalam pentas global dan selalu dapat memberikan solusi dan melakukan antisipasi yang lebih dini terhadap problem-problem umat. ${ }^{26}$

Kelima metode pengembangan Ilmu Dakwah yang diuraikan di atas, dapat diterapkan secara terpisah atau bekerja masing-masing dan dapat juga dengan cara penggabungan. Jika dilakukan dengan cara penggabungan, maka hal ini dapat disebut dengan pendekatan transmetode. Selain itu, untuk masa depan perlu dipikirkan dan dirumuskan metode baru baik berdasarkan pendekatan deduktif yang digali dari Alquran dan Sunnah maupun berdasarkan pengalaman gerakan dakwah selama ini atau pendekatan induktif-empiris.

\section{PENUTUP}

Instrumen untuk pengembangan metode keilmuan dakwah adalah melalui penelitian yang serius. Tugas ini tampaknya tidak bisa diharapkan dari para dai, sebab mereka lebih konsentrasi para aplikasi dakwah. Untuk itu, tugas akbar ini, diperlukan kehadiran pemikir dakwah. Dosen Fakultas Dakwah harus mengambil tanggung jawab ini dengan serius. Kalau bukan mereka, lalu siapa lagi yang berkewajiban menemukan dan merumuskan formulasi dakwah yang lebih antisipatif. Namun dalam pengamatan yang terbatas, tampaknya belum banyak yang berminat ke arah itu.

Kemudian hasil penelitian tersebut perlu dibahas bersama para da'i. Mereka perlu diminta pandangan dan kritikannya untuk revisi dan perbaikan sehingga perumusan konsep baru yang lebih kokoh. Cara ini kuat duguaan belum banyak dilakukan dalam rangka pengembangan Ilmu Dakwah. Namun ke depan usaha bersama antara pakar, peneliti dan praktisi dakwah (dai) mutlak diperlukan guna

\footnotetext{
${ }^{26}$ Ahmad, Dakwah Islam Sebagai..., h. 42-43.
} 
melahirkan konsep dakwah yang lebih aplikatif dalam pemecahan berbagai problematika umat di zaman modern.

\section{DAFTAR PUSTAKA}

Abdullah, Ilmu Dakwah: Kajian Ontologi, Epistemologi, Aksiologi dan Aplikasi Dakwah. Bandung: Citapustaka Media, 2015.

, Dakwah Kultural dan Struktural, Bandung: Citapustaka Media, 2013.

Abdullah, M. Amin, Islamic Studies di Perguruan Tinggi. Yogyakarta: Pustaka Pelajar, 2006.

Ahmad, Amrullah (Ed.), Dakwah Islam dan Perubahan Sosial, Yogyakarta: Prima Duta, 1983.

Ahmad, Amrullah, "Sistem Pendidikan Fakultas dakwah, dalam Media Dakwah, N0.241, Juli 1994.

, Dakwah Islam Sebagai Ilmu, Makalah pada Pertemuan Dekan, Medan: Fakultas Dakwah IAIN Sumatera Utara, 1996.

Amin, Samsul Munir, Rekonstruksi Pemikiran Dakwah, Jakarta: Amzah, 2008. , Ilmu Dakwah, Jakarta: Amzah, 2009.

Aziz, Moh. Ali, Ilmu Dakwah, Jakarta: Prenada Media, 2015.

Bakhtiar, Amsal, Filsafat Agama: Wisata Pemikiran dan Kepercayaan Manusia, Jakarta: RajaGrafindo Persada, 2007. , Filsafat Ilmu, Jakarta: RajaGrafindo Persada, 2010.

Basit, Abdul, Filsafat Dakwah, Jakarta: RajaGrafindo Persada, 2013.

Husaini, Adian, Filsafat Ilmu: Perspektif Barat dan Islam, Jakarta: Gema Insani, 2013.

Idri, Epistemologi Ilmu Pengetahuan, Ilmu Hadis dan Ilmu Hukum Islam, Jakarta: Prenada Media, 2015.

Ismail, A. Ilyas dan Prio Hotman, Filsafat Dakwah: Rekayasa Membangun Agama dan Peradaban, Jakarta: Prenada Media, 2011.

, Paradigma Dakwah Sayyid Quthub: Rekonstruksi Pemikiran Dakwah Harakah, Jakarta: Penamadani, 2008.

Jujun S. Suriasumantri, Ilmu Dalam Perspektif, Jakarta: Yayasan Obor Indonesia, 1983.

, Filsafat Ilmu:Sebuah Pengantar Populer, Jakarta: Pustaka Sinar Harapan, 1993.

Kusnawan, Aep, Demensi Ilmu Dakwah, Bandung: Widya Padjadjaran, 2009.

Kusnawan, Aep, (Ed), Ilmu Dakwah: Kajian Berbagai Aspek, Bandung: Pustaka Bani Quraisy, 2004. 
Lubis, Nur A. Fadhil, Rekonstruksi Pendidikan Tinggi Islam, Medan, UIN Press, 2015.

Mababaya, Norlain Dindang, Da'wah According to The Qur'an and The Sunnah, Riyadh: Darussalam, 1998.

Mulkhan, Abdul Munir, Paradigma Intelektual Muslim, Pengantar Filsafat, Pendidikan Islam dan Dakwah, Yogyakarta: Sipress, 1993.

Pimay, Awaluddin, Paradigma Dakwah Humanis: Strategi dan Metode Dakwah Prof. KH. Saifuddin Zuhri, Semarang: RaSAIL, 2005.

Qomar, Mujamil, Epistemologi Pendidikan Islam, Jakarta: Erlangga, 2005.

Rakhmat, Jalaluddin, Rekayasa Sosial, Bandung: Remaja Rosdakarya, 2000.

Riyanto, Waryani Fajar, Studi Islam Indonesia: Annual International Conference on Islamic Studies, Yogyakarta: Kurnia Kalam Semesta, 2014.

Shihab, M. Quraish Tafsir Al-Mishbah: Pesan, Kesan dan Keserasian Al-Qur'an, Jakarta: Lentera Hati, 2006.

Solihin, Sohirin M, Islamic Da'wah: Theory and Practice, Kuala Lumpur: IIUM Press, 2008.

Subandi, Ahmad. Ilmu Dakwah. Bandung: Syahida, 1994.

Sulthon, Muhammad, Desain Ilmu Dakwah, Yogyakarta: Pustaka Pelajar, 2003.

Zaprulkhan, Filsafat Ilmu: Sebuah Analisis Kontemporer, Jakarta: RajaGrafindo Persada. 2016. 